\title{
Role of New Appetite Hormones Ghrelin, Orexin-A and Obestatin in the Mechanism of Healing of Chronic Gastric Ulcers
}

\author{
Thomas Brzozowski Aleksandra Szlachcicㄹ, Robert Pajdo', Zbigniew \\ Sliwowski ${ }^{1}$, Danuta Drozdowicz ${ }^{1}$, Jolanta Majka ${ }^{1}$, Wladyslaw Bielanski ${ }^{1}$, \\ Peter. C. Konturek ${ }^{2}$, Stanislaw J. Konturek ${ }^{1}$ and Wieslaw W. Pawlik ${ }^{1}$ \\ ${ }^{1}$ Department of Physiology, Jagiellonian University Medical College, Cracow \\ 2Thuringia-Clinic Saalfeld Georgiou's Agricola GmbH Teaching \\ Hospital of the University of Jena, \\ ${ }^{1}$ Poland \\ ${ }^{2}$ Germany
}

\section{Introduction}

The regulation of appetite is regulated by complex mechanism involving brain-gut axis and hormonal and non-hormonal factors acting through the activity of satiety and hunger centers located in the hypothalamus [Wren \& Bloom, 2007]. Among hormones controlling appetite are gastrointestinal hormones such as cholecystokinin, PYY, pancreatic polypeptide, glucagon-like peptide 1, oxyntomedulin, the endocrine pancreatic hormones including insulin and glucagon and endocannabinoids [Wren \&Bloom, 2007]. Recent discoveries of ghrelin and orexin-A gave a new insight into the understanding of mechanism of appetite control, satiety and obesity. Ghrelin is a novel 28-amino acid peptide that has recently been discovered in rat and human gastrointestinal tract, particularly in gastric mucosa, as an endogenous ligand for growth hormone (GH) secretagogue receptor (GHS-R) [Kojima et al., 1999]. Ghrelin stimulates food intake and body weight gain exerting a modulating effect on energy expenditure acting through afferent nerves and directly on hypothalamic feeding centers [Kojima et al., 1999; Tomasetto et al., 2000]. This peptide was also shown to enhance the gastric motility and gastric secretion [Tschop et al., 2000; Date et al., 2001]. Ghrelin is considered as an orexigenic peptide produced by the stomach, acting as a meal initiator [Masuda et al., 2000; Ariyasu et al., 2001]. Little is known about other factors that might affect ghrelin secretion in the stomach and its influence on gastrointestinal integrity has not been fully elucidated. A recent study in humans revealed that stomach is a major source of circulating ghrelin and that gastrectomy produced dramatic fall in the plasma ghrelin levels, whereas fasting and anorexia nervosa was accompanied by elevated plasma ghrelin levels [Ariyasu et al., 2001].

The orexins also called hypocretins, are neuropeptides novel originally discovered in a small group of neurons in the hypothalamic area (LHA) [Sakurai et al., 1998; de Lecea et al., 1998]. identified two peptides that were endogenous ligands to orphan receptor HFGAN72 [Sakurai et al., 1998]. They found that these peptides after i.c.v. injection stimulated food 
intake and their expression was upregulated upon fasting. Therefore, the group of these peptides has been named "orexins" after the Greek word "orexis" meaning appetite [Komaki et al., 2001]. The orexin group of peptides was originally identified as regulators of food intake and of sleep behavior and act at one or the other of $2 \mathrm{G}$ protein-coupled receptors, the orexin-1 (OX-R1) and orexin-2 (OX-R2) receptors [Sakurai et al., 1998; Mondal et al., 1999]. OX-A is a 33-residue peptide possessing the identical sequence in humans and rodents, whereas human and rat OX-B differ by two residues. OX-A and OX-B activate two $\mathrm{G}$ protein-coupled receptors known as OX-1 and OX-2, the OX-1 receptor having a greater affinity for OX-A over OX-B, whereas the OX-2 receptor has similar affinity for both ligands [Sakurai, 2003]. Besides the presence in the brain, orexin-like immunoreactivity was found in the ENS of different species including guinea pig, rat, mouse and humans [Kirchgessner \& Liu, 1999]. Interestingly, the prepro-orexin, orexin $\mathrm{A}$ and orexin receptor mRNA expression were demonstrated in the myenteric plexus and afferent nerves co-localizing with VIP-ergic nerves and in the gastrin-producing cells of the rat stomach [Kirchgessner \& $\mathrm{Liu}, 1999$ ]. Orexin-A has been linked with the peripheral energy balance and central nervous system mechanisms that coordinate sleep-wakefulness and motivated behaviors such as food seeking, especially in physiological state of fasting stress [Mondal et al., 1999; Sakurai, 2003]. Recent studies in humans revealed that the plasma orexin-A concentrations are increased during fasting in humans [Komaki et al., 2001].

The question remains as to whether these newly discovered peptides could play a role in the mechanism of gastric integrity and gastric mucosal defense has not been fully explored. Both, ghrelin and orexin-A were implicated in the mechanism of gastroprotection but their role in the healing process of chronic gastric ulcers has been little investigated. Previous studies by [Sibilia et al., 2003] and our group [Brzozowski et al., 2004; Brzozowski et al., 2006 b.; Konturek et al., 2004] revealed that that central and peripheral administration of ghrelin reduced the formation of acute gastric lesions induced by ethanol and cold stress. It was proposed that $\mathrm{NO}$ and sensory neuropeptides mediate these gastroprotective effects of ghrelin because the blockade of NO-synthase (NOS) activity with L-NAME and the functional ablation of sensory afferent nerves with capsaicin attenuated the protection and gastric hyperemia induced by ghrelin [Brzozowski et al., 2004; Brzozowski et al., 2006a.; Dimitrova et al., 2010]. In contrast to prevention of acute damage to the mucosal structure, the healing of chronic gastric ulcers lasts days and weeks and may involve restoration of gland architecture, angiogenesis and scar formation and it remains unknown whether appetite hormones may influence these processes.

Recently, endogenous prostaglandins (PG) have been implicated in the control of food intake and appetite [Lugarini et al., 2002; Scholz, 2003] but the possibility that these arachidonate metabolites may play any important role in the mechanism of ghrelin or orexin-A affecting ulcer healing has not been explored. This prompted our interest in endogenous PG because these arachidonate metabolites play an essential role in the mechanism of gastric defense and ulcer healing [Brzozowski et al., 2001] but the importance of PG derived from cyclooxygenase (COX-1) and COX-2 in the possible ulcer healing effects of orexigenic peptides has not been so far determined.

This study was designed to compare the effects of daily intraperitoneal (i.p.) administration of vehicle, ghrelin, orexin-A and obestatin on healing of preexisting gastric ulcers and accompanying changes in the gastric blood flow (GBF) at ulcer margin and the generation of $\mathrm{PGE}_{2}$ in the gastric mucosa. An attempt was made to examine the effect of antagonism of 
GHS-R1a and OX-A1 receptors with D-lys'3GHRP-6 and SB334867 [Peeters, 2005; Smart et al., 2001] respectively, on spontaneous ulcer healing and the alteration in ulcer size induced by ghrelin and orexin-A. We also determined the effects of PG inhibition with a nonselective (indomethacin) and selective cyclooxygenase (COX)-1 (SC-560) and COX-2 (rofecoxib) inhibitors and blockade with L-NNA, the NO-synthase inhibitor on healing of these ulcers and accompanying changes in the GBF in rats without and with ghrelin or orexin-A administration. In addition, the expression of ghrelin mRNA at the ulcer margin and that in non-ulcerated gastric mucosa was assessed in rats with gastric ulcer. Finally, ghrelin rats were concomitantly treated with obestatin to check whether obestatin, recently considered as physiological opponent of ghrelin regarding food intake and appetite control [Zhang et al., 2005], could influence the ulcer healing itself and affect the healing and hyperemic effects of ghrelin.

\section{Material and methods}

Male Wistar rats, weighing 200-250 g and fasted for $24 \mathrm{~h}$ were used in all studies. All experimental procedures were run according to Helsinki Declaration and approved by the Jagiellonian University Institutional Animal Care and Use Committee.

\subsection{Production of gastric ulcers}

Gastric ulcers were produced in rats using our modification (19) of acetic acid method originally proposed by Okabe et al. (1971) with our group modification [Konturek et al., 1987]. Animals were anesthetized with ether, the stomach was exposed and $75 \mu \mathrm{l}$ of acetic acid was poured through the plastic mold $(6 \mathrm{~mm}$ diameter) onto serosal surface of anterior wall of the stomach just proximal to the antral gland area for $25 \mathrm{~s}$. This produced an immediate necrosis of the entire mucosa and submucosa (but not serosa) within the area where the acetic acid was applied, i.e., about $28 \mathrm{~mm}^{2}$. The excess of acetic acid was then removed and the serosa was gently washed out with saline. Our previous studies documented that these ulcers became chronic within 2-3 days and healed completely within 2-3 weeks without perforation or penetration to the surrounding organs as described in original technique [Konturek et al., 1987; Okabe et al., 1971]. After the application of acetic acid the animals were allowed to recover from anesthesia and received only water at the day of operation (day 0). Then, they were divided into various groups and received normal chow and water ad libitum for the next 9 days and then were sacrificed.

\subsection{Effect of orexin-A, ghrelin without and with the antagonists of ghrelin and orexin-A receptors on ulcer healing and the alterations in GBF at ulcer margin}

Several groups of rats with gastric ulcers, each consisting of 6-8 animals, were treated daily either with 1) vehicle (saline), 2) ghrelin or orexin-A (2.5-30 $\mu \mathrm{g} / \mathrm{kg}$-d i.p.), 3) D-Lys ${ }^{3}-\mathrm{GHRP}-6$ (200 $\mu \mathrm{g} / \mathrm{kg}$ i.p.), the ghrelin receptor antagonist (Peeters, 2005), or SB 334867 which is a selective non-peptide OX-R1 receptor antagonist [Smart, et al., 2001; Holland, et al., 2006] administered alone or in the combination with ghrelin and orexin-A (standard dose of 30 $\mu \mathrm{g} / \mathrm{kg}$-d i.p.), respectively. SB 334867 was dissolved in DMSO and kept in a $20 \mathrm{mM}$ solution as recommended by manufacturer [Tocris Cookson Ltd., Bristol, UK]. The dose of OX-R1 antagonist used in this study was selected on the basis of our earlier studies (unpublished 
observation) with dose-dependent inhibition of orexin-A protection against WRS damage obtained with this orexin-A antagonist.

In another group of animals with gastric ulcers and treated with COX-1 and COX-2 inhibitors with or without ghrelin, orexin-A and obestatin administration, the effect of prostaglandin replacement therapy using 16,16 dimethyl PGE 2 [Upjohn, Kalamazoo, MI, USA] applied i.g. in a dose of $5 \mu \mathrm{g} / \mathrm{kg}$-d was examined. This dose of dimethyl $\mathrm{PGE}_{2}$ was found in our preliminary study to be without any influence on ulcer healing and accompanying fall in GBF at ulcer margin. For this reason, synthetic $\mathrm{PGE}_{2}$ analog was administered together with each COX-1 or COX-2 inhibitor with or without ghrelin, orexinA and obestatin administration.

Upon the termination of experiment, the animals were anesthetized with pentobarbital, their abdomen was opened by midline incision and the stomach exposed for measurement of GBF by means of the $\mathrm{H}_{2}$-gas clearance technique as described previously [Brzozowski et al., 2000 a]. For this purpose two electrodes of an electrolytic regional blood flow meter (Biotechnical Science, Model RBF-2, Osaka, Japan) were inserted into the gastric mucosa. The measurements were made in three areas of the oxyntic mucosa at ulcer margin and the mean values were calculated and expressed as percent changes of those recorded in the control animals. After GBF measurement, the stomach was removed, rinsed with saline and pinned open for macroscopic examination. The area of gastric lesions was determined by computerized planimetry (Morphomat, Carl Zeiss, FRG) [Brzozowski et al., 2000 b] by a researcher blind to the experimental grouping.

Samples of the oxyntic gland area from the ulcer margin were taken by biopsy (about 100 $\mathrm{mg}$ ) immediately after the animals were sacrificed to determine the mucosal generation of $\mathrm{PGE}_{2}$ by specific radioimmunoassay (RIA) as described previously [Konturek et al., 1995; Brzozowski et al., 2000]. PGE 2 was measured in duplicate using RIA kits (New England Nuclear, Munich, Germany). The mucosal generation of $\mathrm{PGE}_{2}$ was expressed in nanograms per gram of wet tissue weight.

\subsection{Effect of ghrelin and orexin-A on the healing of acetic acid ulcers and accompanying changes in the GBF at ulcer margin. Involvement of the COX-PG and NO-NOS systems in ghrelin-induced acceleration of ulcer healing}

The involvement of the COX-PG system in the ulcer healing effects of ghrelin was studied in rats treated with (or without) indomethacin, a non-selective COX-1 and COX-2 inhibitor, and with SC-560, a selective COX-1 inhibitor or rofecoxib, a specific COX-2 inhibitor [Brzozowski et.al., 1999]. In the experimental protocol, the following groups of rats, each consisting of 6-8 animals, were used: 1) vehicle (saline $1 \mathrm{ml}$ i.p.); 2) ghrelin, orexin-A or obestatin, each applied in a standard dose of $30 \mu \mathrm{g} / \mathrm{kg}-\mathrm{d}$ i.p.; 2$)$ indomethacin $(5 \mathrm{mg} / \mathrm{kg}$ i.p.), SC-560 (5 mg/kg-d i.g.) and rofecoxib (10 mg/kg-d i.g.), each applied alone or coadministered with ghrelin, orexin-A or obestatin $(30 \mu \mathrm{g} / \mathrm{kg}-\mathrm{d}$ i.p.). The doses of SC-560 and rofecoxib were selected on the basis of previous studies showing that these agents almost completely suppress $\mathrm{PGE}_{2}$ generation in exudates of air-pouch inflammation and inhibit gastric $\mathrm{PGE}_{2}$ production in mucosa with preexisting gastric ulcer [Futaki et al., 1993; Lesch et al., 1998]. SC-560 (Cayman Chemical Co., Ann Arbor, Michigan, USA) was first dissolved in absolute ethanol to obtain a stock solution of $50 \mathrm{mg} / \mathrm{ml}$ and then diluted to the desired concentration with isotonic saline. Rofecoxib [Sharp \& Dhome, Warsaw, Poland] was first dissolved in methanol to obtain a stock solution $75 \mathrm{mg} / \mathrm{ml}$ and then diluted to the desired 
concentration with isotonic saline. Control rats received the corresponding vehicle. Our preliminary studies (data not included) showed that none of the COX inhibitors used in this study produced by itself any gastric lesions at the doses tested. At the dose used in the present study, indomethacin has been shown previously to inhibit gastric $\mathrm{PGE}_{2}$ generation by $\sim 90 \%$ without itself causing any mucosal damage [Konturek et al., 1987].

In another group of animals with gastric ulcers and treated with COX-1 and COX-2 inhibitors with or without ghrelin, orexin-A and obestatin administration, the effect of prostaglandin replacement therapy using 16, 16 dimethyl PGE 2 (Upjohn, Kalamazoo, MI, USA) applied i.g. in a dose of $5 \mu \mathrm{g} / \mathrm{kg}$-d was examined. This dose of dimethyl $\mathrm{PGE}_{2}$ was found in our preliminary study to be without any influence on ulcer healing and accompanying fall in GBF at ulcer margin. For this reason, synthetic $\mathrm{PGE}_{2}$ analog was administered together with each COX-1 or COX-2 inhibitor with or without ghrelin, orexinA and obestatin administration.

Upon the termination of experiment, the animals were anesthetized with pentobarbital, their abdomen was opened by midline incision and the stomach exposed for measurement of GBF by means of the $\mathrm{H}_{2}$-gas clearance technique as described previously [Brzozowski et al., 2000 a]. For this purpose two electrodes of an electrolytic regional blood flow meter (Biotechnical Science, Model RBF-2, Osaka, Japan) were inserted into the gastric mucosa. The measurements were made in three areas of the oxyntic mucosa at ulcer margin and the mean values were calculated and expressed as percent changes of those recorded in the control animals. After GBF measurement, the stomach was removed, rinsed with saline and pinned open for macroscopic examination. The area of gastric lesions was determined by computerized planimetry (Morphomat, Carl Zeiss, FRG) [Brzozowski et al., 2000b] by a researcher blind to the experimental grouping.

Samples of the oxyntic gland area from the ulcer margin were taken by biopsy (about 100 $\mathrm{mg}$ ) immediately after the animals were sacrificed to determine the mucosal generation of $\mathrm{PGE}_{2}$ by specific radioimmunoassay (RIA) as described previously [Konturek et al., 1995]. $\mathrm{PGE}_{2}$ was measured in duplicate using RIA kits (New England Nuclear, Munich, Germany). The mucosal generation of $\mathrm{PGE}_{2}$ was expressed in nanograms per gram of wet tissue weight.

\subsection{Determination of plasma ghrelin, orexin-A and obestatin levels by radioimmunoassay}

At the termination of some experiments with obestatin applied i.p. alone or coadministered with ghrelin, the rats were anesthetized with pentobarbital and blood samples (about $3 \mathrm{ml}$ ) taken from the vena cava for the measurement of plasma ghrelin, orexin-A and obestatin levels by RIA. Intact rats fasted overnight and given only vehicle (saline) i.p. were measured similarly in order to determine control values for plasma ghrelin, orexin-A and obestatin concentration. Blood samples were collected in heparin coated polypropylene tubes and centrifuged at $3000 \mathrm{rpm}$ for 20 minutes at $4{ }^{\circ} \mathrm{C}$. The supernatant was then stored at $-80^{\circ} \mathrm{C}$ until measurement of plasma ghrelin, orexin-A and obestatin levels using an RIA-kit for rat ghrelin, orexin-A and obestatin (Phoenix Peptide, Belmont, CA, USA) [Brzozowski et al., 2004; Brzozowski et. al., 2006 b]. Briefly, the ghrelin, orexin-A and obestatin RIA involved the competition of each rat peptide sample with ${ }^{125}$ I-rat ghrelin, orexin-A and obestatin tracers for binding to a specific rabbit anti-ghrelin-, anti-orexin-A- and antiobestatin polyclonal antibody. The limit of assay sensitivity for ghrelin, orexin-A and 
obestatin were $3 \mathrm{pg}$, $6 \mathrm{pg}$ and 5 pg per tube, the intra-assay variation was less than $8 \%, 7 \%$ and $9 \%$, and the interassay variation less than $5 \%, 4 \%$ and $7 \%$, respectively.

\subsection{Reverse-transcriptase-polymerase chain reaction (RT-PCR) for detection of messenger RNA (mRNA) for ghrelin and proinflammatory cytokines IL-1 $\beta$ and TNF- $\alpha$ in rats without and with gastric ulcers}

The stomachs were removed from vehicle (control) rats for the determination of ghrelin mRNA expression using specific primers by RT-PCR. Gastric mucosal specimens were scraped off from oxyntic mucosa using a slide glass and immediately snap frozen in liquid nitrogen and stored at $-80^{\circ} \mathrm{C}$ until analysis. Total RNA was extracted from mucosal samples by a guanidium isothiocyanate/phenol chloroform method using a kit from Stratagene ${ }^{\circledR}$ (Heidelberg, Germany). Single stranded cDNA was generated from $5 \mu \mathrm{g}$ of total cellular RNA using StrataScript reverse transcriptase and oligo-(dT)-primers (Stratagene, Heidelberg, Germany). The polymerase chain reaction mixture was amplified in a DNA thermal cycler (Perkin-Elmer-Cetus, Norwalk, CT) in an area set aside for performing the PCR reaction. The nucleotide sequences of the primers for ghrelin and $\beta$-actin were selected on the basis of the published cDNA encoding ghrelin and $\beta$-actin, respectively [Konturek et al., 2004; Brzozowski et al., 2006 b]. The sense primer for ghrelin was 5'TTGAGCCCAGAGCACCAGAAA-3', and the antisense primer was ${ }^{\prime}$ 'AGTTGCAGAGGAGGCAGAAGCT-3'. The IL-1 $\beta$ primer sequences were designed according to the published cDNA sequence for primer sequences and were as follows: upstream, 5' GCT ACC TAT GTC TTG CCC GT; downstream, 3' GAC CAT TGC TGT TTC CTA GG. The expected length product was $543 \mathrm{bp}$. The TNF- $\alpha$ primer sequences were as follows: up-stream, 5'TAC TGA ACT TCG GGG TGA TTG GTC C; downstream, 3' CAG CCT TGT CCC TTG AAG AGA ACC. The expected length product was $295 \mathrm{bp}$ [Konturek et al., 2010]. The oligonucleotide sequences for $\beta$-actin were TTG TAA CCA ACT GGG ACG ATA TGG (sense) and GAT CTT GAT CTT CAT GGT GCT AGG (antisense). The primers were synthesized by GIBCO BRL/Life Technologies, Eggenstein, Germany. The signals for ghrelin mRNA was standardized against the $\beta$-actin signal for each sample and results were expressed as the ratio of ghrelin mRNA to $\beta$-actin mRNA.

\section{Results}

\subsection{Effect of treatment with orexin-A, ghrelin and obestatin on ulcer healing and the accompanying changes in the GBF at ulcer margin}

The effect of i.p. administration of orexin-A applied in graded doses ranging from 1 $\mu \mathrm{g} / \mathrm{kg}-\mathrm{d}$ up to $30 \mu \mathrm{g} / \mathrm{kg}-\mathrm{d}$ and ghrelin administered in a dose of $30 \mu \mathrm{g} / \mathrm{kg}-\mathrm{d}$ (i.p.) on acetic acid-induced gastric ulcers are shown in Fig.1. Orexin-A dose-dependently reduced the ulcer area, the dose inhibiting this area by $50 \%\left(\mathrm{ED}_{50}\right)$ was $15 \mu \mathrm{g} / \mathrm{kg}$.

Almost double reduction of the ulcer area was obtained with orexin-A administered at the dose $30 \mu \mathrm{g} / \mathrm{kg}$ as compared with control rats injected i.p. with vehicle (saline). This reduction in ulcer area achieved with orexin-A was accompanied by the dose-dependent increase in GBF. Ghrelin administered in a dose of $30 \mu \mathrm{g} / \mathrm{kg}$-d i.p. significantly reduced the ulcer area and significantly increased GBF with the extent similar to that observed with orexin-A applied in the highest dose. Eight days of i.p. administration of obestatin applied in graded doses ranging from $2.5 \mu \mathrm{g} / \mathrm{kg}$ up to $30 \mu \mathrm{g} / \mathrm{kg}-\mathrm{d}$, dose-dependently reduced the 


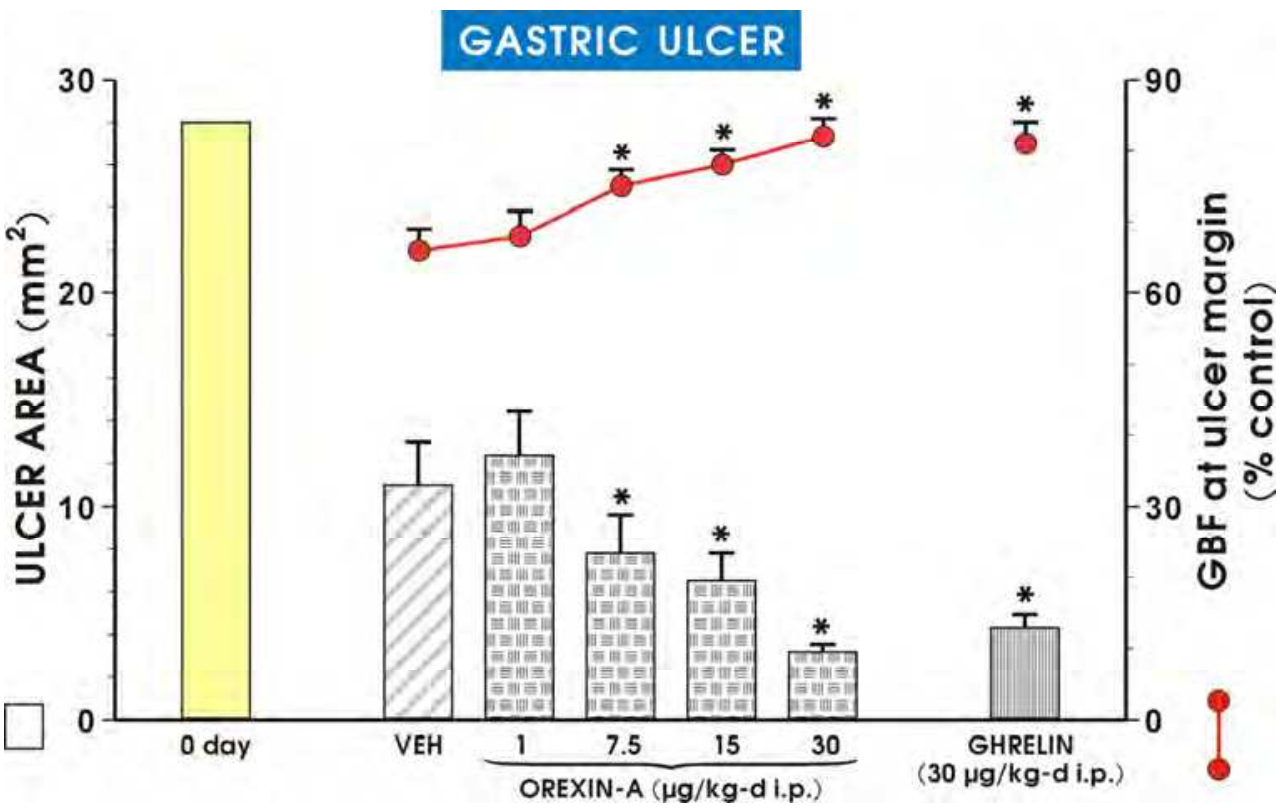

Fig. 1. The area of gastric ulcer induced by acetic acid and gastric blood flow (GBF) at ulcer margin at 8 day upon ulcer induction in rats treated with vehicle (saline) or with various doses of orexin-A ( 1 - $30 \mu \mathrm{g} / \mathrm{kg}$-d i.p.) or ghrelin (30 $\mu \mathrm{g} / \mathrm{kg}-\mathrm{d}$ i.p.). Means \pm SEM of 6-8 rats. Asterisk indicates a significant change $(\mathrm{p}<0.05)$ as compared to the vehicle-control values.

area of gastric ulcer and significantly increased the GBF at ulcer margin starting from the dose of $5 \mu \mathrm{g} / \mathrm{kg}$ (Fig. 2). The maximal reduction of ulcer area accompanied by a significant rise in the GBF at ulcer margin was recorded at the dose of $30 \mu \mathrm{g} / \mathrm{kg}$ of obestatin where $35 \%$ reduction of ulcer area and an increase by about $19 \%$ of GBF at ulcer margin were observed as compared to the respective values in vehicle-treated animals.

\subsection{Role of cyclooxygenase (COX)-1 and COX-2 inhibition and the blockade of nitric oxide (NO) synthase on ulcer healing activity and alterations in the GBF at ulcer margin in rats treated with ghrelin, orexin-A and obestatin}

As shown in Fig. 3, ghrelin and orexin-A given i.p. in dose $30 \mu \mathrm{g} / \mathrm{kg}$-d significantly decreased ulcer area and enhanced GBF as compared to those observed in vehicle. Treatment with D-Lys ${ }^{3}-G H R S-6(200 \mu \mathrm{g} / \mathrm{kg}$ i.p.), the ghrelin GHS-R1a receptor antagonist, by itself failed to affect the area of gastric ulcers and GBF at ulcer margin at day 8 upon ulcer induction. The decrease in the area of these ulcers and accompanying rise in the GBF at ulcer margin induced by ghrelin and orexin-A were significantly attenuated by concurrent treatment with ghrelin and orexin-A receptor antagonists, D-Lys3-GHRS-6 and SB334867. The administration of $\mathrm{D}$-lys ${ }^{3} \mathrm{GHRP}$, which is a specific ghrelin receptor antagonist or SB334867, an antagonist of orexin-A OXR-1 receptors when applied alone, failed to affect the area of gastric ulcer and the GBF at ulcer margin as compared to those measured in vehicletreated rats. Treatment with D-lys ${ }^{3}$ GHRP significantly attenuated ghrelin-induced acceleration of ulcer healing and the accompanying increase in GBF at ulcer margin. 
Concomitant treatment of orexin-A with its receptor antagonist, SB334867 (5 mg/kg-d s.c.), completely abolished the reduction in ulcer area induced by orexin-A. This antagonist of orexin-A receptors reversed also an increase in GBF at ulcer margin caused by orexin-A.

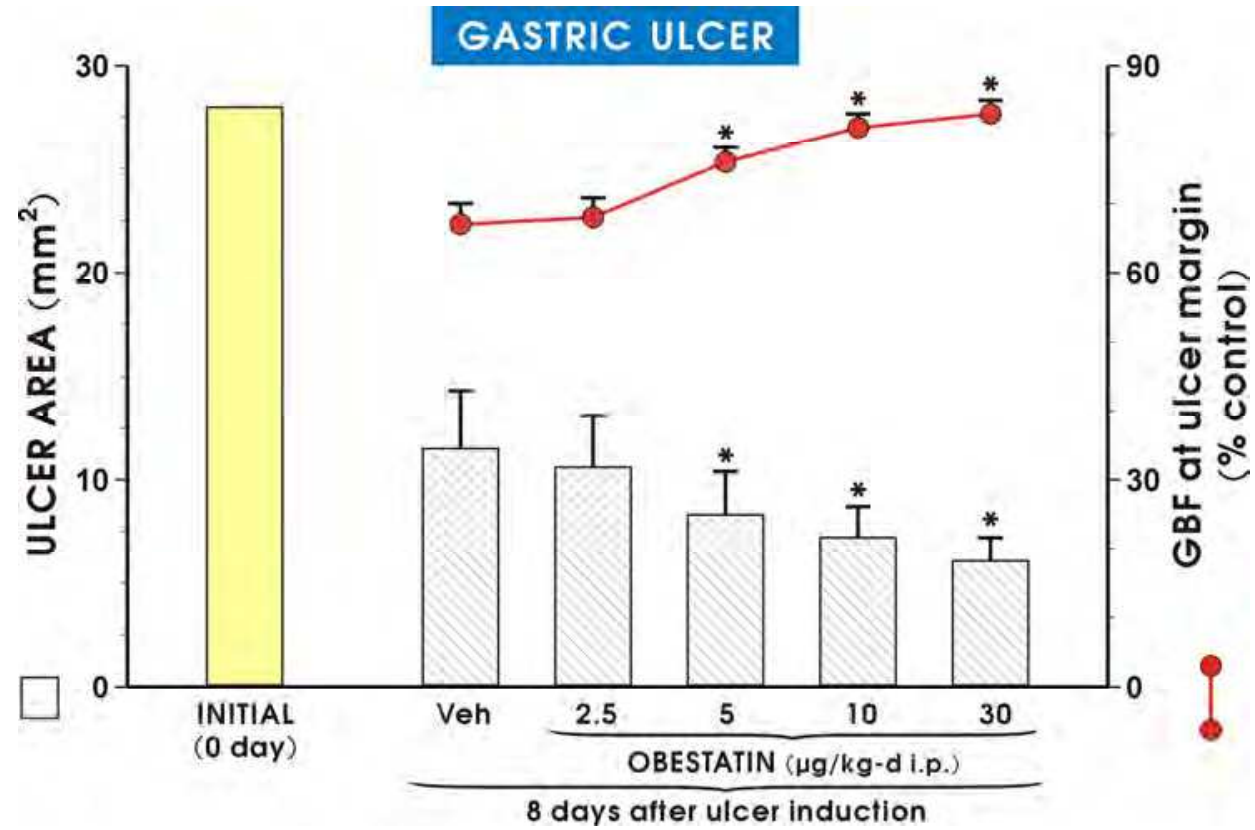

Fig. 2. The area of gastric ulcers and the alterations in the GBF at ulcer margin in rats treated for 8 days with vehicle (Veh; control) or obestatin applied i.p. in graded doses ranging from $2.5 \mu \mathrm{g} / \mathrm{kg}$-d up to $30 \mu \mathrm{g} / \mathrm{kg}$-d. Mean \pm SEM of $6-8$ rats. Asterisk indicates a significant change $(\mathrm{p}<0.05)$ compared to the vehicle-pretreated controls.

As shown in Fig. 4, treatment with ghrelin, orexin-A and obestatin (30 $\mu \mathrm{g} / \mathrm{kg}-\mathrm{d}$ i.p.) resulted in a similar attenuation in the area of gastric ulcer and a similar rise in GBF as that shown in Figs. 1 and 2. The mucosal generation of $\mathrm{PGE}_{2}$ was significantly increased at ulcer margin as compared to the respective value in the non-ulcerated control $(128 \pm 9 \mathrm{vs} .189 \pm 12 \mathrm{ng} / \mathrm{g}$ wet tissue weight, $\mathrm{p}<0.05)$. Ghrelin, orexin-A and obestatin applied i.p. resulted in a significant increase in the $\mathrm{PGE}_{2}$ generation at ulcer margin as compared to vehicle-treated animals with gastric ulcer $(189 \pm 12$ vs $234 \pm 19 \mathrm{ng} / \mathrm{g}, 189 \pm 12 \mathrm{vs} 228 \pm 9 \mathrm{ng} / \mathrm{g}$ and $189 \pm 12$ vs $219 \pm 8 \mathrm{ng} / \mathrm{g}$, respectively, $\mathrm{p}<0.05)$. Indomethacin $(5 \mathrm{mg} / \mathrm{kg}$ i.p.), which by itself significantly increased the ulcer area, suppressed the generation of $\mathrm{PGE}_{2}$ by about $85 \%(\mathrm{p}<0.02)$ and produced a significant fall in GBF as compared to vehicle-pretreated animals (Fig. 4). Treatment with this non-selective COX-1 and COX-2 inhibitor completely abolished the reduction in the area of gastric ulcers and the accompanying rise in GBF evoked by ghrelin, orexin-A and obestatin. The decrease in the area of ulcer and accompanying increase in GBF caused by ghrelin, orexin$\mathrm{A}$ and obestatin as well as the rise in the $\mathrm{PGE}_{2}$ generation they induced were also significantly attenuated by pretreatment with rofecoxib, the selective COX-2 inhibitor (Fig. 4). SC-560 (5 $\mathrm{mg} / \mathrm{kg}$-d i.g.), which by itself significantly reduced the $\mathrm{PGE}_{2}$ generation (not shown), significantly attenuated the ghrelin-, orexin-A- and obestatin-induced decrease in ulcer area 
and the accompanying rise in GBF at ulcer margin (Fig. 4). Concurrent treatment with a minute amount of synthetic dimethyl analog of $\mathrm{PGE}_{2}(5 \mu \mathrm{g} / \mathrm{kg}-\mathrm{d}$ i.g.) in addition to ghrelin, orexin-A and obestatin restored the decrease in the ulcer area and the increase in GBF at ulcer margin in rats treated with indomethacin, SC-560 or rofecoxib (Fig. 4).

\section{GASTRIC ULCER}

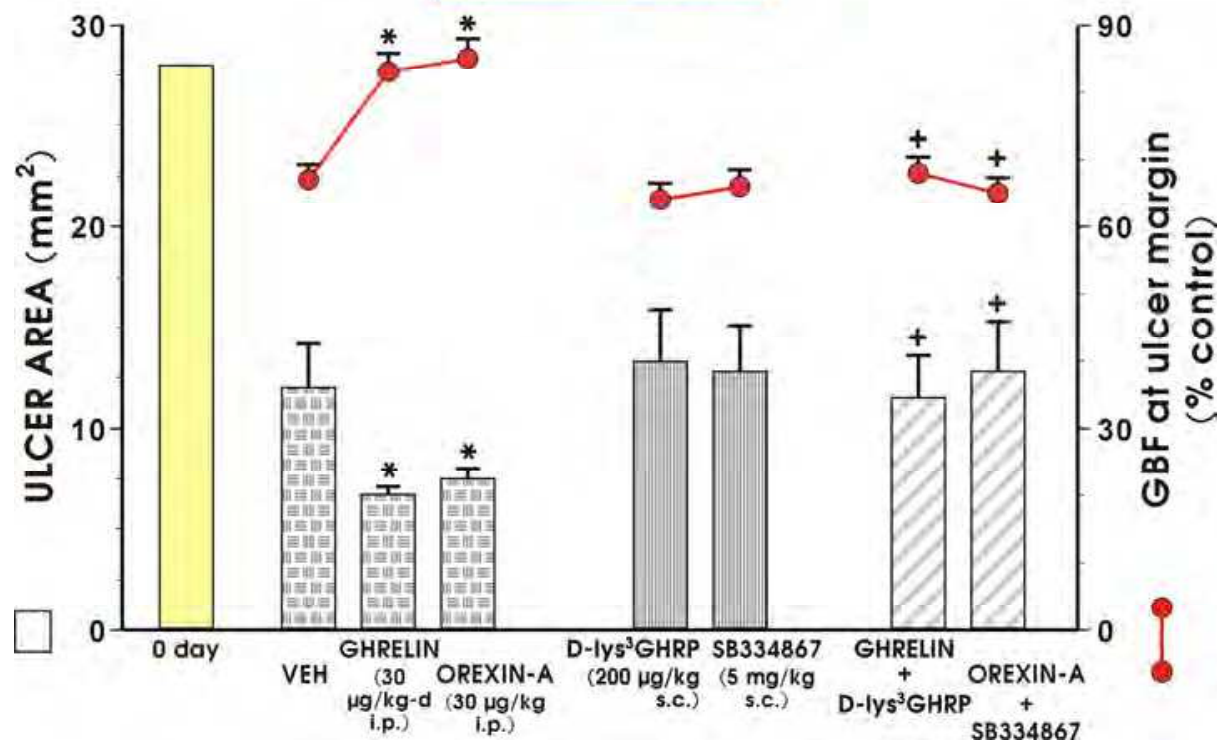

Fig. 3. The area of gastric ulcers and the accompanying changes in the GBF at ulcer margin in rats with or without ghrelin or orexin-A (both at a dose of $30 \mu \mathrm{g} / \mathrm{kg}$-d i.p.) applied without or with the ghrelin receptor antagonist D-Lys3-GHSR-6 $(200 \mu \mathrm{g} / \mathrm{kg}$-d i.p.) or orexinA receptor antagonist SB334867 (200 $\mu \mathrm{g} / \mathrm{kg}$-d i.p.). Mean \pm SEM of 6-8 rats. Asterisk indicates a significant change $(\mathrm{p}<0.05)$ compared to the vehicle-pretreated controls. Cross indicates a significant change $(\mathrm{p}<0.05)$ compared to the values obtained in rats treated with ghrelin and orexin-A without the concurrent treatment with GHS-R1a receptor or OXR-1 receptor antagonists.

\subsection{Expression of ghrelin and proinflammatory cytokines in ulcer area during ulcer healing without and with ghrelin treatment}

The effect of eight day administration of L-NNA (20 mg/kg-d i.p.), the NO-synthase inhibitor on ulcer area and the changes in GBF at ulcer margin in rats treated without and with vehicle, ghrelin, orexin-A and obestatin, each applied in a dose of $30 \mu \mathrm{g} / \mathrm{kg}$-d i.p. is presented in Fig. 5. Treatment with ghrelin, orexin-A and obestatin significantly reduced the ulcer area and increased the GBF at ulcer margin as shown in Fig. 4. Treatment with LNNA, which by itself significantly enhanced ulcer area also significantly decreased GBF at ulcer margin as compared to respective values in vehicle-control. Concurrent treatment with L-NNA together with ghrelin, orexin-A and obestatin reversed the ghrelin-, orexin-A- and obestatin-induced decrease in ulcer area and the accompanying rise in the GBF at ulcer margin. 
Fig. 6 shows that ghrelin was expressed in intact non-ulcerated gastric mucosa and that with gastric ulcer. Ghrelin mRNA expression was detected as the strong signal in intact gastric mucosa and vehicle-treated gastric mucosa with gastric ulcer. Ratio of mRNA for ghrelin over $\beta$-actin revealed that this ratio was significantly higher in ulcerated gastric mucosa as in case of that in intact animals without an ulcer (Fig. 6, left panel).

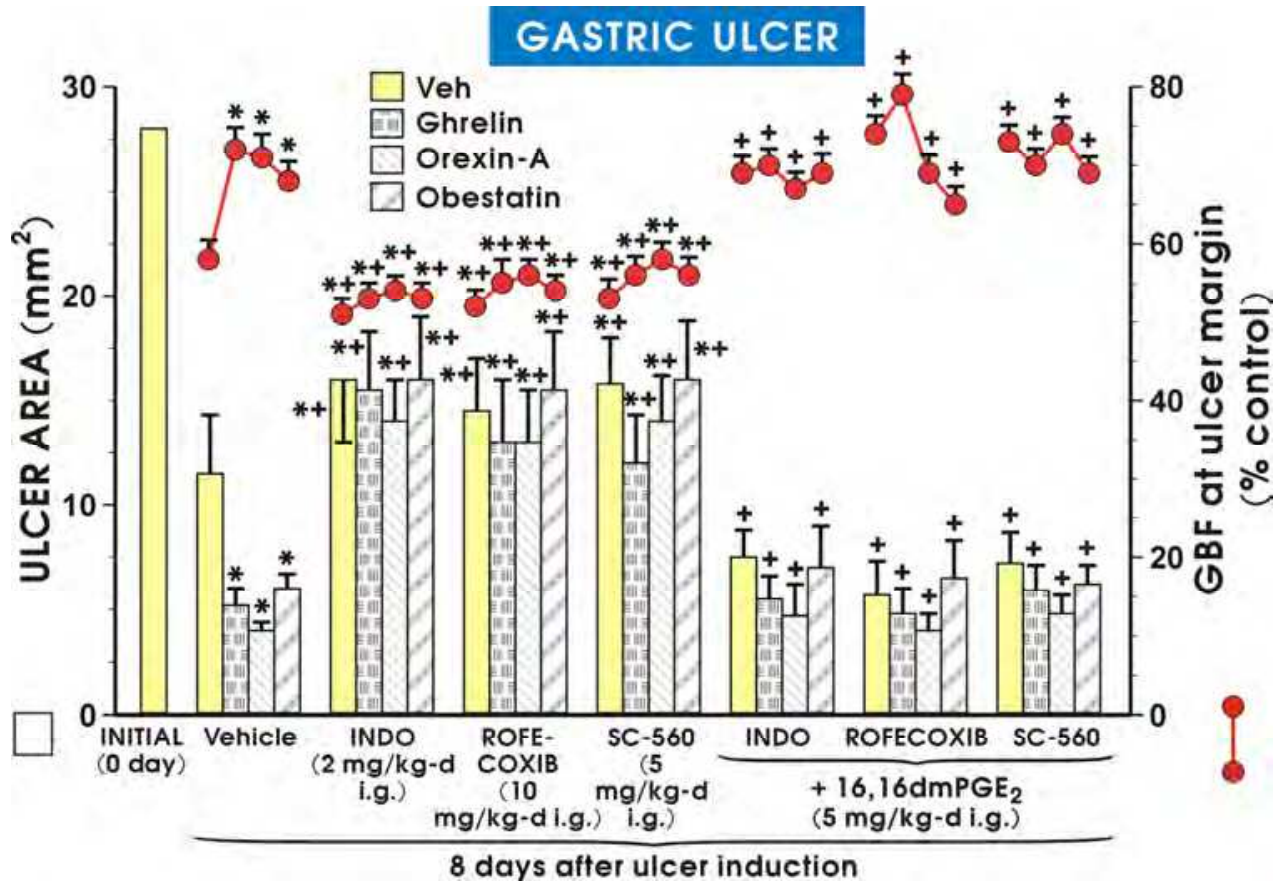

Fig. 4. The area of gastric ulcers and the accompanying changes in the GBF at ulcer margin in rats treated for a period of 8 days with vehicle (saline) and ghrelin, orexin-A and obestatin (each given in a dose of $30 \mu \mathrm{g} / \mathrm{kg}$-d i.p.) with or without the concurrent treatment with indomethacin ( $5 \mathrm{mg} / \mathrm{kg}$-d i.p.), rofecoxib (10 mg/ kg-d i.g.) or SC-560 (5 mg/ kg-d i.g.) applied alone or combined with synthetic 16,16 dimethyl $(\mathrm{dm}) \mathrm{PGE}_{2}$ analog $(5 \mu \mathrm{g} / \mathrm{kg}-\mathrm{d}$ i.g.). Mean \pm SEM of 6-8 rats. Asterisk indicates a significant decrease $(p<0.05)$ as compared to the value obtained in vehicle-controls. Asterisk and cross indicate a significant increase $(p<0.05)$ as compared to vehicle-treated controls administered without or with ghrelin, orexin-A or obestatin. Cross indicate a significant change $(\mathrm{p}<0.02)$ as compared to respective values obtained in animals treated with indomethacin, SC-560 or rofecoxib without the concurrent treatment with $\mathrm{PGE}_{2}$ analog.

As shown in Fig. 7, the signal of mRNA for IL-1 $\beta$ and TNF- $\alpha$ mRNAs was faintly expressed in intact gastric mucosa but it was observed as strong signal in vehicle-control mucosa of animals with gastric ulcer. Ratio of mRNA for ghrelin over $\beta$-actin indicated that expression of mRNA for IL-1 $\beta$ and TNF- $\alpha$ was significantly increased in vehicle-treated rats with gastric ulcer over that recorded in intact gastric mucosa. In contrast, in rats treated with ghrelin applied i.p. at the doses of $15 \mu \mathrm{g} / \mathrm{kg}$ and $30 \mu \mathrm{g} / \mathrm{kg}$, the signal for IL- $1 \beta$ and TNF- $\alpha$ 
mRNAs was significantly decreased in gastric mucosa with gastric ulcer as compared to that in vehicle-control animals. Ratio of mRNA for IL- $1 \beta$ and TNF- $\alpha$ mRNA over $\beta$-actin mRNA revealed that this ratio was significantly decreased in gastric mucosa of rats treated with ghrelin administered at the dose of $15 \mu \mathrm{g} / \mathrm{kg}$. The ratio of IL- $1 \beta$ and TNF- $\alpha$ was significantly decreased in animals treated with ghrelin applied i.p in a higher dose of $30 \mu \mathrm{g} / \mathrm{kg}$ than in those treated with ghrelin administered in a lower dose of $15 \mu \mathrm{g} / \mathrm{kg}$ of this peptide (Fig. 7).

\section{GASTRIC ULCER}

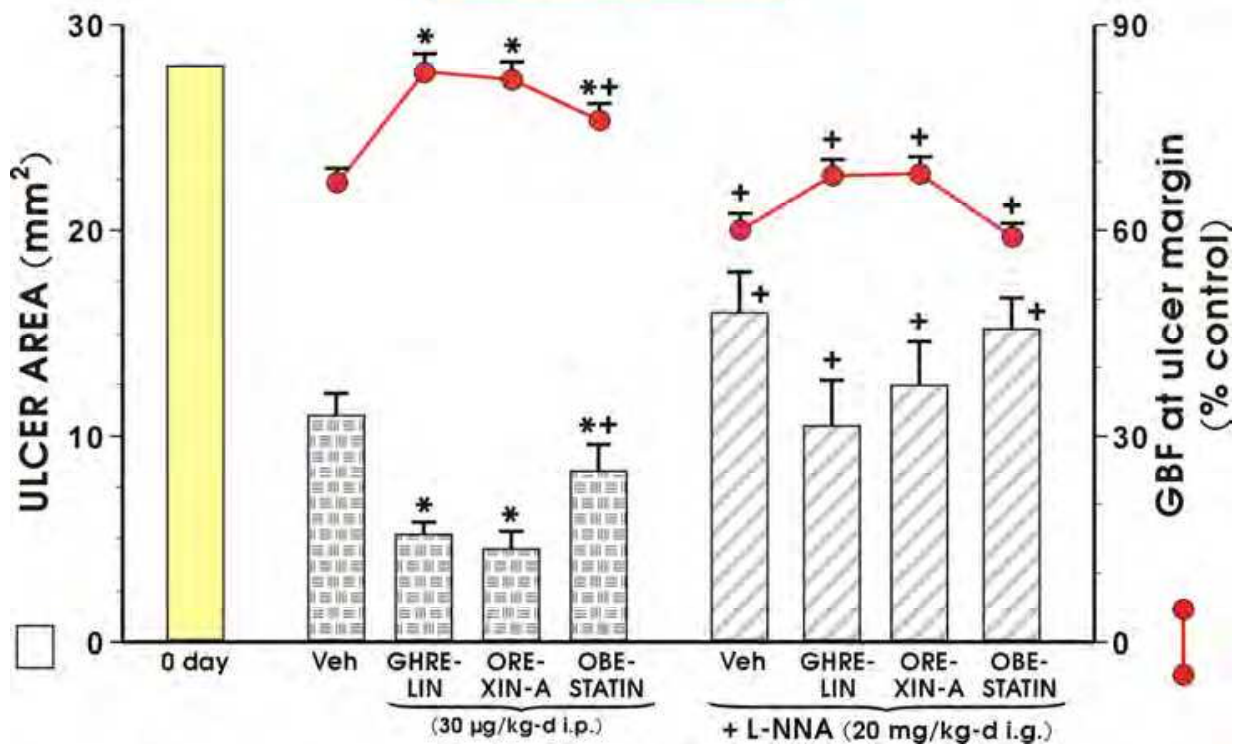

Fig. 5. The area of gastric ulcers and the accompanying changes in the GBF at ulcer margin in rats treated with vehicle (Veh; saline-control), ghrelin, orexin-A and obestatin (each administered in a dose of $30 \mu \mathrm{g} / \mathrm{kg}$-d i.p.) applied without or with the NO-synthase inhibitor L-NNA (20 mg/kg-d i.p.). Mean \pm SEM of 6-8 rats. Asterisk indicates a significant change $(\mathrm{p}<0.05)$ compared to the vehicle-treated controls. Asterisk and cross indicate a significant change $(\mathrm{p}<0.05)$ compared to the values obtained in rats treated with vehicle. Cross indicates the significant change $(p<0.02)$ compared to the values obtained in ghrelin, orexin-A and obestatin without the concurrent treatment with L-NNA.

\subsection{Effect of treatment with obestatin on ulcer healing in rats with of ghrelin administration}

Fig. 8 shows the effects of eight day of concomitant administration of ghrelin, the appetite stimulating peptide, and obestatin which is opponent of ghrelin acting as the natural ligand of the GPR39 receptor, on the alterations in area of gastric ulcer and accompanying changes in GBF at ulcer area and plasma ghrelin and obestatin levels. Ghrelin and obestatin given i.p. in the same comparable dose of $30 \mu \mathrm{g} / \mathrm{kg}$ - $\mathrm{d}$ significantly reduced the area of gastric ulcer, however the significantly greater reduction in ulcer area was observed in ghrelin- 

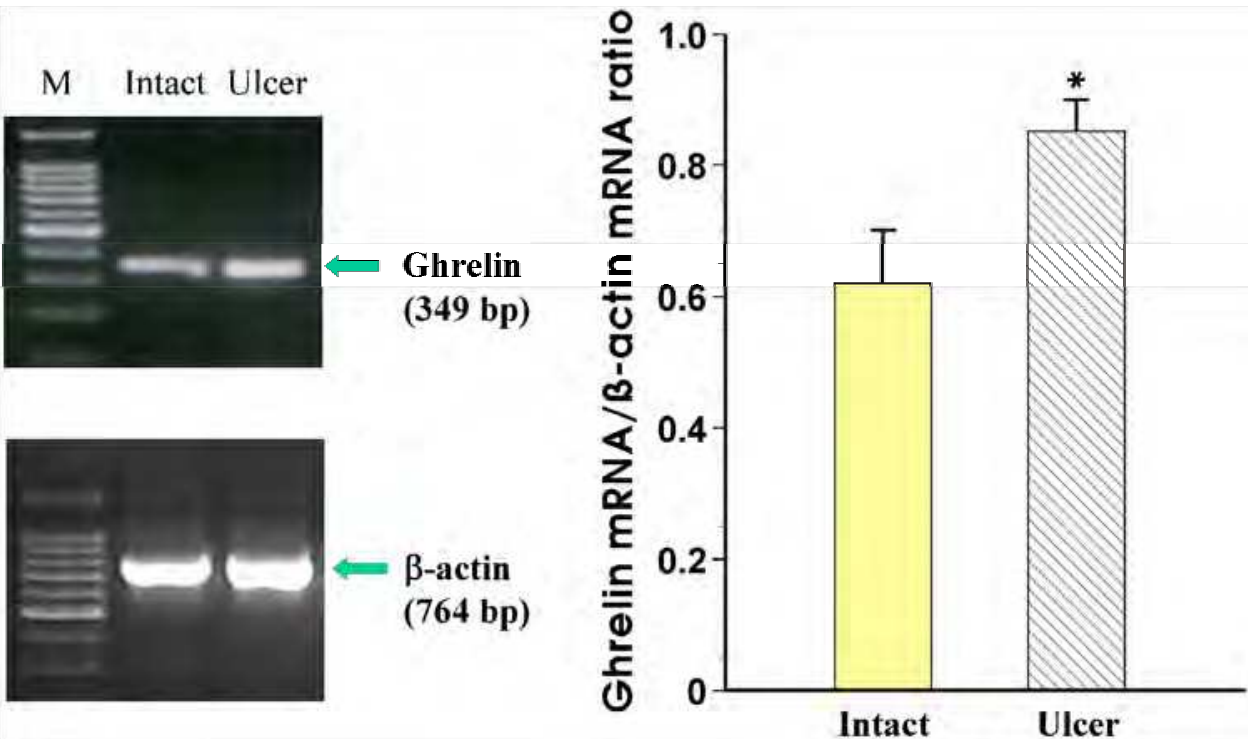

\section{Intact Ulcer}

Fig. 6. Determination of expression of $\beta$-actin and ghrelin mRNAs (left panel) by RT-PCR and the ratio of ghrelin to $\beta$-actin mRNA (right panel) in non-ulcerated (intact) gastric mucosa (lane Intact) and in gastric mucosa at ulcer margin (lane Ulcer), M - DNA size marker. Mean \pm SEM of 4- 6 rats. Asterisk indicates a significant change $(p<0.05)$ as compared to the value obtained in non-ulcerated gastric mucosa.

treated rats as compared with those treated with obestatin. Plasma ghrelin level increased after i.p. administration of exogenous ghrelin but remained unchanged after combined treatment of ghrelin with obestatin as compared with those treated with ghrelin alone. The plasma obestatin concentration which was significantly increased in obestatin-treated rats with gastric ulcer was not significantly affected by the concurrent ghrelin administration as compared to vehicle-treated rats. The combined treatment of obestatin co-administered with ghrelin failed to significantly the affect the ghrelin-induced attenuation of ulcer area and the accompanying rise in plasma ghrelin level which reached similar values, as in case of ghrelin administered alone.

\section{Discussion}

This study shows that appetite hormones such as ghrelin, orexin-A and obestatin besides their well recognized action in the control of food intake and energy expenditure, exhibit ulcer healing and hyperemic activities as documented by an acceleration of ulcer healing by these peptides accompanied by an increase in the GBF at ulcer margin. These healing and hyperemic effects of ghrelin and orexin A seem to be very specific because both hormones induced acceleration of the healing and hyperemia at ulcer margin were reversed by ghrelin receptor antagonist D-Lys3-GHRP-6, and orexin-A receptor antagonist SB 334867, respectively, indicating that ghrelin- and orexin A-induced ulcer healing promoting and hyperemic effects are mediated by the functionally active form of GHS-R1a receptor and orexin (OX-R1) receptors. These receptors GHS-R1a and OX-R1 have been shown to bind 


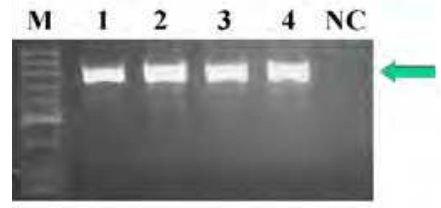

\section{$\beta$-actin \\ (764 bp)}
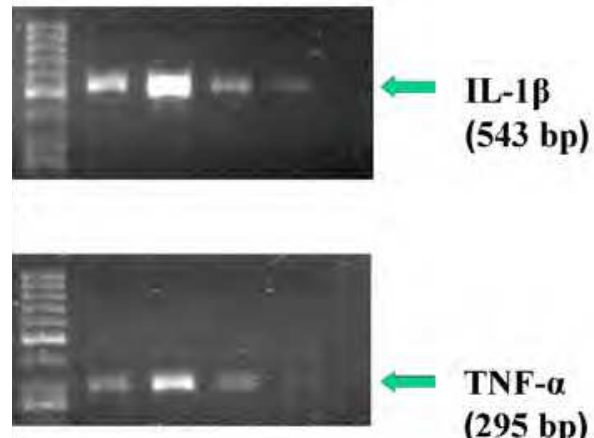
(295 bp)
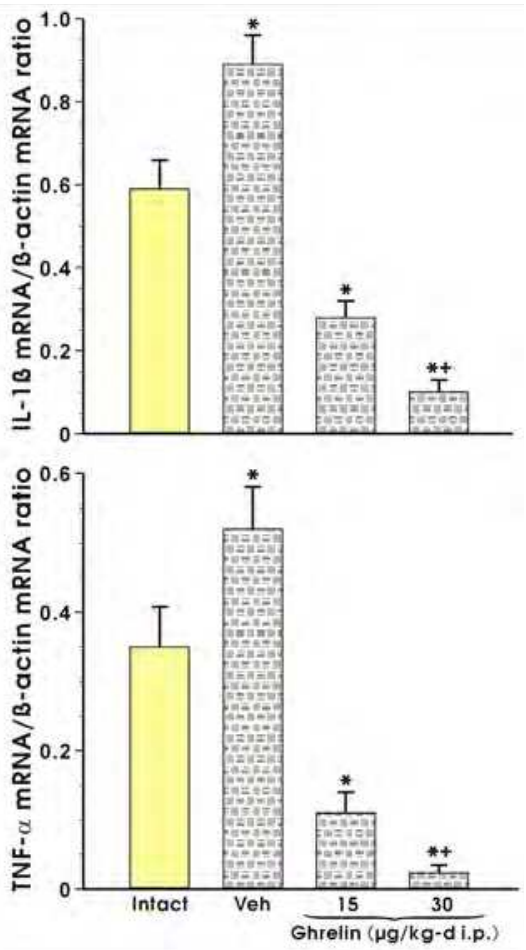

Fig. 7. Determination of expression of $\beta$-actin, IL-1 $\beta$ and TNF- $\alpha$ mRNAs (left panel) by RTPCR and the ratio of mRNA for ghrelin, orexin-A and obestatin (each administered at the dose of $30 \mu \mathrm{g} / \mathrm{kg}$-d i.p.) to $\beta$-actin mRNA (right panel) in intact non-ulcerated gastric mucosa and in those with acetic acid-induced gastric ulcer treated with vehicle (saline) or ghrelin applied i.p. in a dose of $15 \mu \mathrm{g} / \mathrm{kg}$ or $30 \mu \mathrm{g} / \mathrm{kg}, \mathrm{M}$ - DNA size marker. Mean \pm SEM of 4-6 rats. Asterisk indicates a significant change $(\mathrm{p}<0.05)$ as compared to the value obtained in intact non-ulcerated gastric mucosa. Asterisk and cross indicate a significant change $(\mathrm{p}<0.05)$ as compared to the value obtained in animals treated eight days with ghrelin administered daily i.p. at the dose of $15 \mu \mathrm{g} / \mathrm{kg}-\mathrm{d}$.

acylated ghrelin and orexin A, respectively. Moreover, we found that ghrelin, orexin A and to lesser extent also obestatin increased the $\mathrm{PGE}_{2}$ generation at ulcer margin and that these peptides ulcer healing promoting and hyperemic effects and an increase in $\mathrm{PGE}_{2}$ generated at ulcer margin were significantly attenuated by non-selective (indomethacin), selective COX-1 (SC-560) and selective COX-2 inhibitors (rofecoxib). These findings indicate that endogenous PG derived from both COX-1 and COX-2 enzymatic pathways are involved in the mechanism of ulcer healing by these hormones. Obestatin which was originally claimed to act as ghrelin opponent in the regulation of appetite behaviour [Zhang et. al., 2005], also accelerated ulcer healing and increased the GBF at ulcer margin in our study though these effects were less pronounced as compared with those of ghrelin and orexin-A.

Ghrelin is a recently described 28-amino acid peptide that has been discovered in rat and human gastrointestinal tract, particularly in gastric mucosa, as an endogenous ligand for 


\section{GASTRIC ULCER}

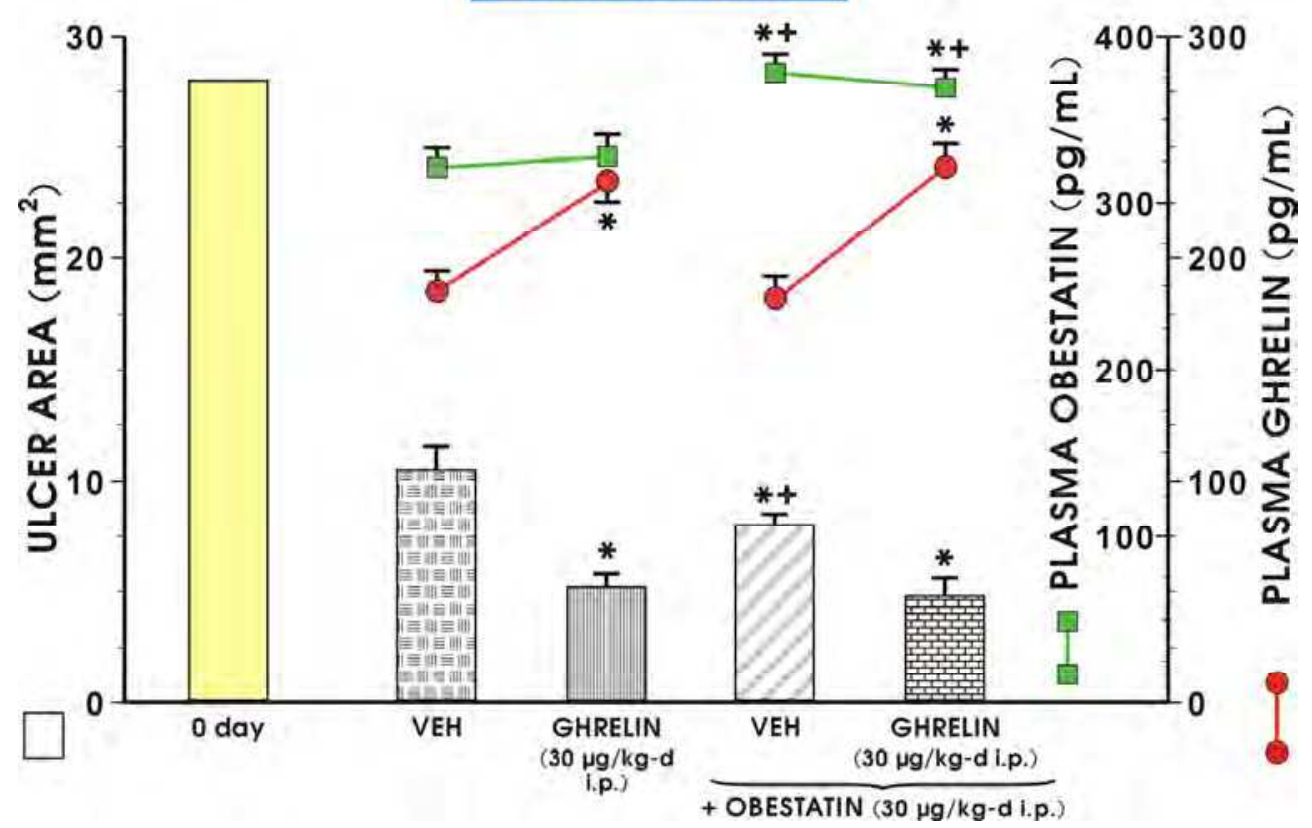

Fig. 8. The area of gastric ulcers and the alterations in the GBF at ulcer margin in rats treated for 8 days with vehicle (Veh, saline) or ghrelin $(30 \mu \mathrm{g} / \mathrm{kg}-\mathrm{d}$ i.p.) without or with concurrent treatment with obestatin $(30 \mu \mathrm{g} / \mathrm{kg}-\mathrm{d}$ i.p.). Mean \pm SEM of $6-8$ rats. Asterisk indicates a significant change $(\mathrm{p}<0.05)$ compared to vehicle-control- or obestatin-treated rats. Asterisk and cross indicate a significant change $(\mathrm{p}<0.05)$ compared to rats treated with ghrelin.

growth hormone secretagogue receptor (GHS-R) [Kojima et al., 1999, Hosoda et. al., 2000]. Previous studies revealed that two GHS-R subtypes are generated by alternative splicing of a single gene: the full-length type 1a receptor (GHS-R1a) and a carboxyl-terminally truncated GHS-R type 1b (GHS-R1b) [Peeters , 2005; Brzozowski et al., 1999]. The GHS-R1a is the functionally active, signal transducing form of the GHS-R, while the GHS-R1b is devoid of high-affinity ligand binding and signal transduction activity. Ghrelin molecules, produced by endocrine cells of gastric glands exist in two major molecular forms, ghrelin and des-n-octanoyl ghrelin (des-acyl ghrelin) [Hosoda et al., 2000; Fukuhara et al., 2005]. The acylation by n-octanoic acid of the hydroxyl group of their third residue, which is either serine or threonine, is essential for binding of ghrelin to the GHS-R1a [Hosoda et al., 2000]. We attempted in this study to determine whether the expected ulcer healing activity of ghrelin and orexin A is due to a direct activation of GHS-1a and orexin A receptors or involves other mediators or receptors, as yet uncharacterized and distinct from the GHS-R and orexin A. We have found that the acceleration of healing and the functional features of this healing such as an improvement in the GBF at ulcer area, the crucial mechanism involved in the healing of gastric ulcer, were mediated by specific ghrelin and orexin-A receptors.

Ghrelin was originally reported to exhibit gastroprotective activity against mucosal lesions induced by corrosive substances such as ethanol as well as against damage induced by 
stress and ischemia-reperfusion [Sibilia et al., 2003; Brzozowski et al., 2004; Konturek et al., 2004; Brzozowski et al., 2006]. These effects were associated with a significant increase in plasma ghrelin concentration as well as marked attenuation of the fall in GBF provoked by stress and I/R but remained independent on gastric acid secretory activity of this peptide [Brzozowski et al., 2006]. This study attempted to determine the effects of graded doses of exogenous orexin-A and obestatin compared with ghrelin on healing of acetic acid ulcers and GBF at ulcer margin and $\mathrm{PGE}_{2}$ generation in the gastric mucosa. We found that peripherally administered orexin-A dose-dependently accelerated ulcer healing, elevated mucosal generation of $\mathrm{PGE}_{2}$ and raised $\mathrm{GBF}$ at ulcer margin. Ghrelin and obestatin also accelerated ulcer healing with the magnitude similar to orexin-A while causing an increase in $\mathrm{GBF}$ and $\mathrm{PGE}_{2}$ generation in the ulcerated gastric mucosa. The key finding of this study is the demonstration that ghrelin mRNA is upregulated in the margin of gastric ulcer suggesting that endogenous ghrelin might reduce the size of the ulcer and improve the microcirculation around the ulcer bed. Interestingly, ghrelin mRNA was also increased in the gastric mucosa exposed to ischemia-reperfusion suggesting that enhanced expression of transcripts of ghrelin may limit the extent of gastric damage provoked by I/R. Thus, our study is in partial agreement with previous observations that plasma ghrelin is increased following stress-induced gastric lesions, and that its enhanced immunoreactivity is associated with duodenal ulcerations induced by cysteamine in rats [Brzozowski et al., 2006; Fukuhara et al., 2005].

Since endogenous prostaglandins (PGs) have been implicated in the control of food intake and appetite [Eberhart, E.C, 1995; Scholz, H, 2003] we hypothesized that these cytoprotective arachidonate metabolites could play an important role in the healing effect of ghrelin. This prompted our interest in endogenous PGs because their role as well as the importance of expression of cyclooxygenase (COX-1) and COX-2 at ulcer margin in the possible ulcer activity of appetite hormones such as ghrelin, orexin-A and obestatin have not been studied. The present study supports the notion that the ulcer healing and hyperemic activities of ghrelin, orexin-A and obestatin during the time-course of ulcer healing involve an increase in mucosal generation of endogenous PGs. Previous studies have established that PG synthesis depends upon the activity of cyclooxygenase (COX), a rate limiting enzyme in the synthesis of eicosanoids from arachidonic acid [Eberhart CE \& Dubois RN, 1995]. In contrast to COX-1, COX-2 is not constitutively expressed in most of tissues, but is dramatically upregulated during inflammation and ulcer healing [Takeuchi et al., 2004; Brzozowski et al., 2006] and following inhibition of mucosal COX-1 activity [Davies et al., 1997; Tanaka et al., 2002; Takeuchi et al., 2004]. First, we found that all hormones tested that is mean ghrelin, orexin $\mathrm{A}$ and obestatin enhance the $\mathrm{PGE}_{2}$ generation at ulcer margin as compared with that of vehicle-control at day 8 upon ulcer induction. Second, indomethacin almost completely abolished, while SC-560, the selective COX-1 inhibitor and rofecoxib, the selective COX-2 inhibitor, greatly attenuated the ulcer healing and hyperemic effects of ghrelin, orexin A and obestatin, indicating that endogenous PGs, potentially derived from the activities of both COX-1 and COX-2, are responsible for the putative beneficial effects of this peptide on ulcer healing. It is of interest that COX-1 and COX-2 inhibitors by themselves delayed ulcer healing and abolished the ulcer healing promoting activity of ghrelin, orexin $A$ and obestatin and counteracted their accompanying rise in GBF at ulcer margin suggesting that endogenous PG might be considered as primary mediators involved in the mechanism of ulcer healing by these peptides. 
It is not excluded that the beneficial effect of these hormones depend also upon the activation of NO/NOS system by these hormones, which is an important metabolic pathway involved in the mechanism of mucosal defense and ulcer healing. The involvement of cNOS/iNOS-NO system in ulcer healing and the possible role of ghrelin in ulcer healing are not quite clear from this and other studies [Sibillia et al., 2009]. Although the nonspecific suppression of cNOS/iNOS-NO system by L-NNA was found in our study to delay ulcer healing, little is known whether appetite hormones could affect the expression and activity of cNOS or iNOS or both. Indeed, the concurrent treatment with L-NNA not only markedly reduced the acceleration of ulcer healing but also the accompanying hyperemia at ulcer margin caused by these hormones. This finding suggests that NO could be considered as one of the essential mediator of both, the ulcer healing and the hyperemic activity of ghrelin, orexin A and obestatin. Thus we propose that NO possibly derived from constitutive cNOS rather than inducible iNOS expression and activity, plays an important role in the ghrelin-, orexin A and obestatin induced acceleration of the ulcer healing process. However, factors other than endogenous PGs and NO, possibly also sensory neuropeptides such as CGRP could also contribute to this effect, and therefore, their involvement in ulcer healing activity of ghrelin, orexin A and obestatin should be addressed in future studies. The finding that COX-1 and COX-2 inhibitors greatly attenuated the ulcer healing activity of ghrelin, is in keeping with the observation that ghrelin is ineffective in the protection against indomethacin-induced gastric ulcers [Sibillia et al., 2004], where the mucosal generation of $\mathrm{PGE}_{2}$ is greatly suppressed.

Interestingly, the overexpression of TNF- $\alpha$ a and IL-1 $\beta$ was detected in vehicle treated control rats with gastric ulcer comparing to intact gastric mucosa, and this effect was probably caused by severe tissue ischemia, resulting from the application of acetic acid. This overexpression of proinflammatory cytokines such as TNF- $\alpha$ and IL-1 $\beta$, likely contributed to early tissue damage and formation of ulceration. As reported by our group recently [Brzozowski et al., 2006] vascular injury leading to ischemia is the major factor associated with early induction of acute mucosal damage and also involved in the time-course of chronic ulceration in the stomach, where the acetic acid was applied. [Guo et al., 2003] reported an early rise in the expression of iNOS, suggesting that this expression accompanied by excessive generation of NO possibly forming peroxynitrate, was probably responsible for the enlargement of ulcer crater observed at early first days upon ulcer induction by acetic acid in rats. Our results seem to support this notion by overexpression of mRNA for proinflammatory cytokines, TNF- $\alpha$ and IL-1 $\beta$, that could be responsible for the formation of focal tissue damage caused by acetic acid application. Treatment with ghrelin markedly attenuated the expression of IL- $1 \beta$ and TNF- $\alpha$ in gastric mucosa around the ulcer suggesting that the acceleration of ulcer healing by ghrelin could be, at least in part, due to the potent anti-inflammatory activity of this hormone.

We reported before that the induction of gastric ulcer by serosal application of acetic acid is accompanied by the co-expression of gastroprotective COX-2-PG system with the increased expression and release of vasoactive, proliferative and trophic gastric hormones such as gastrin and ghrelin [Konturek et al., 2008]. Ghrelin was shown to exhibit gastroprotective activity and our present study confirming that this hormone can accelerate ulcer healing, suggests that the upregulation in the ghrelin gene expression could play the central event in the mechanism of gastric ulcer healing. These protective and trophic hormonal responses of gastric mucosa to ulceration, as manifested by increased expression of ghrelin co-expressed 
with COX-2 [Konturek et al., 2008] possibly triggered by an overexpression of IL-1 $\beta$ and $\mathrm{TNF}-\alpha$, seem to play a crucial role in the restoration cellular and glandular structure of the mucosa and the quality of ulcer healing.

Interestingly, obestatin, which is encoded by the same gene as ghrelin has recently been reported to counteract physiological effects of ghrelin [Zhang et al., 2005]. Intraperitoneal and intracerebroventricular treatment with obestatin suppressed food intake in a timedependent and dose-dependent manner. This was supported by observation that obestatin effectively blunted the hunger caused by short-term starvation and inhibited feeding or body weight in rats [Sibillia et al., 2009] and food consumption in mice [Lagaut et al., 2007]. However, the vast majority of studies indicates that obestatin exerts little or no effects on food intake and body weight and failed to modify the CCK-induced decrease in food intake [Moechrs et al., 2006; Nogueiras et al., 2007; Tremblay et al., 2007]. Our present findings are in keeping with these latter observations because obestatin by itself accelerated ulcer healing but when administered together with ghrelin, remained without influence on ghrelin induced promotion of the ulcer healing and an increase in the GBF at ulcer margin and plasma ghrelin levels. This suggests that obestatin might not be considered as physiological opponent of ghrelin with the respect to ulcer healing activity which clearly was enhanced by this peptide.

\section{Conclusion}

In summary, these results demonstrate for the first time, that administration of exogenous ghrelin dose-dependently accelerates healing of chronic gastric ulcers and that other hormones involved in the control of appetite and food intake such as orexin-A and obestatin can also exert beneficial effect on the speed of ulcer healing. An evidence was provided that these ulcer healing effects of orexin-A, ghrelin and obestatin may depend upon endogenous PGs derived from COX-1 and COX-2 activity and an enhancement of gastric microcirculation around the ulcer area, possibly mediated by NO. Our finding that ghrelin is expressed in gastric mucosa, particularly at ulcer margin during ulcer healing suggests that this hormone may act locally by paracrine pathway to activate the vasoactive compounds such as PG and NO that may lead to an acceleration of the ulcer healing and the suppression of the mucosal expression and the release of proinflammatory cytokines TNF- $\alpha$ and IL-1 $\beta$.

\section{References}

Ariyasu, H.; Takaya, K.; Tagami, T.; Ogawa, Y.; Hosoda, K; Akamizu, T.; Suda, M.; Koh, T.; Natsui, K.; Toyooka, S.; Shirakami, G.; Usui, T.; Shimatsu, A.; Doi, K.; Hosoda, H.; Kojima, M.; Kangawa, K. \& Nakao, K. (2001). Stomach is a major source of circulating ghrelin, and feeding state determines plasma ghrelin-like immunoreactivity levels in humans. Journal Clinical Endocrinology and Metabolism, Vol.86, No.10, pp.4753-4758, ISSN 0021-972X

Brzozowski, T.; Konturek, P.C.; Konturek, S.J; Sliwowski, Z.; Drozdowicz, D.; Stachura, J.; Pajdo, R. \& Hahn, E.G. (1999). Role of prostaglandins generated by cyclooxygenase- 1 and cyclooxygenase- 2 in healing of ischemia-reperfusion- 
induced gastric lesions. European Journal Pharmacology, Vol.385, No.1, pp. 47-61, ISSN 0014-2999.

Brzozowski, T.; Konturek, P.C.; Konturek, S.J.; Drozdowicz, D.; Kwiecien, S.; Pajdo, R.; Bielanski, W. \& Hahn, E.G. (2000a). Role of gastric acid secretion in progression of acute gastric erosions induced by ischemia-reperfusion into gastric ulcers. European Journal of Pharmacology, Vol.398, No.1, pp.147-158, ISSN 0014-2999.

Brzozowski, T.; Konturek, P.C.; Konturek, S.J.; Pierzchalski, P.; Bielanski, W.; Pajdo, R.; Drozdowicz, D.; Kwiecien, S. \& Hahn, E.G. (2000b). Central leptin and cholecystokinin in gastroprotection against ethanol-induced damage. Digestion, Vol.62, No.2-3, pp.126-142, ISSN 0012-2823.

Brzozowski, T.; Konturek, P.C.; Konturek, S.J.; Sliwowski, Z.; Pajdo, R.; Drozdowicz, D.; Ptak, A. \& Hahn, E.G. (2001). Classic NSAID and selective cyclooxygenase (COX)-1 and COX-2 inhibitors in healing of chronic gastric ulcers. Microscopy Research and Technique, Vol.53, No.5, pp. 343-353, ISSN:1059-910X.

Brzozowski, T.; Konturek, P.C.; Konturek, S.J.; Kwiecien, S.; Drozdowicz, D.; Bielanski, W.; Pajdo, R.; Ptak, A.; Nikiforuk, A.; Pawlik, W.W. \& Hahn, E.G. (2004). Exogenous and endogenous ghrelin in gastroprotection against stress-induced gastric damage. Regulatory Peptides, Vol.120, No.1-3, pp.39-51, ISSN 0167-0115.

Brzozowski, T.; Konturek, P.C.; Sliwowski, Z.; Drozdowicz, D.; Kwiecien, S.; Pawlik, M.; Pajdo, R.; Konturek, S.J.; Pawlik, W.W. \& Hahn EG. (2006a). Neural aspects of ghrelin-induced gastroprotection against mucosal injury induced by noxious agents. Journal Physiology and Pharmacology, Vol.57, Suppl.6, pp.63-76, ISSN 08675910.

Brzozowski, T.; Konturek, P.C.; Sliwowski, Z.; Pajdo, R.; Drozdowicz, D.; Kwiecien, S. (2006b). Prostaglandin/cyclooxygenase pathway in ghrelin-induced gastroprotection against ischemia-reperfusion injury. Journal of Pharmacology and Experimental Therapeutics, Vol.319, No.1, pp.447-487, ISSN 0022-3565.

Date, Y.; Nakazato, M.; Murakami, N.; Kojima, M.; Kangawa, K. \& Matsukura, S. (2001). Ghrelin acts in the central nervous system to stimulate gastric acid secretion. Biochemical and Biophysical Research Communication, Vol.280, No.3, pp.904-907, ISSN 0006-291X.

Davies, N.M.; Sharkley, K.A.; Asfaha, S.; MacNaughton, W.K. \& Wallace, J.L. (1997). Aspirin causes rapid up-regulation of cyclooxygenase-2 expression in the stomach of rats. Alimentary Pharmacology \& Therapeutics, Vol.11, No.6, pp.11011108, ISSN 0269-2813.

de Lecea, L.; Kilduff, T.S.; Peyron, C.; Gao, X.B.; Foye, P.E.; Danielson, P.E. ; Fukuhara, C.; Battenberg, E.L.; Gautvik, V.T.; Bartlett, F.S.; Frankel, W.N.; van den Pol, A.N.; Bloom, F.E.; Gautvik, K.M \& Sutcliffe, J.G. (1998) The hypocretins: hypothalamusspecific peptides with neuroexcitatory activity. Proceedings of the National Academy of Sciences of the USA, Vol.95, No.1, pp.322-327, ISSN 0027-8424.

Dimitrova, D.Z.; Dimitrov, S.D.; Iliev, I.; Mladenov, MI.; Hristov, K.L.; Mihov, DN.; Duridanova, D.B. \& Gagov, H.S. (2010). Ghrelin signaling in human mesenteric arteries. Journal Physiology and Pharmacology. Vol. 61, No 4, pp. 383-390, ISSN 0867-5910. 
Eberhart, C.E. \& Dubois RN. (1995). Eicosanoids and the gastrointestinal tract. Gastroenterology, Vol.109, No.1, pp.285-301, ISSN 0016-5085.

Fukuhara, S.; Suzuki, H.; Masaoka, T.; Arakawa, M.; Hosoda, H.; Minegishi, Y.; Kanagawa, K.; Ishii, H.; Kitajima, M. \& Hibi T. (2005). Enhanced ghrelin secretion in rats with cysteamine-induced duodenal ulcers. American Journal of Physiology, Vol.289, No.1, pp.G139-G145, ISSN 0002-9513.

Futaki, N.; Yoshikawa, K.; Hamasaka, Y.; Arai, I.; Higuchi, S.; Izuka, H. \& Otomo, S. (1993). NS-398, a novel non-steroidal anti-inflammatory drug with potent analgesic and antipyretic effects which causes minimal stomach lesions. General Pharmacology. Vol. 24, No.1, pp.105-110, ISSN 0306-3623.

Guo, J.S., Cho, C.H., Wang, W.P., Shen, X.Z., Cheng, C.L., Koo, M.W. (2003). Expression and activities of three inducible enzymes in the healing of gastric ulcers in rats. World J Gastroenterol. Vol. 9, No. 8, pp.1767-71, ISSN 1007-9327.

Holland, P.R.; Akerman, S. \& Goadsby, P.J. (2006). Modulation of nociceptive dural intput to the trigeminal nucleus caudalis via activation of the orexin 1 receptor in the rat. European Journal of Neuroscience, Vol.24, No.10, pp.2825-2833, ISSN 0953-816X.

Hosoda, H.; Kojima, M.; Matsuo, H. \& Kangawa, K. (2000). Ghrelin and des-acyl ghrelin: two major forms of rat ghrelin peptide in gastrointestinal tissue. Biochemical and Biophysical Research Communications, Vol.279, No.3, pp.909-913, ISSN 0006-291X.

Kirchgessner, A.L. \& Liu, M.T. (1999). Orexin synthesis and response in the gut. Neuron, Vol.24, No.4, pp.941-951, ISSN 0896-6273.

Kojima, M.; Hosoda, H.; Date, Y.; Nakazo, M.; Matsuo, H. \& Kangawa, K. (1999). Ghrelin is a growth-hormone-releasing acylated peptide from stomach. Nature, Vol.402, No.6762, pp.656-660, ISSN 00228-0836.

Komaki, G.; Matsumoto, Y.; Nishikata, H.; Kawai, K.; Nozaki, T.; Takii, M.; Sogawa, H. \& Kubo, C. (2001). Orexin-A and leptin change inversely in fasting non-obese subjects. European Journal of Endocrinology, Vol.144, No.6, pp.645-651, ISSN 08044643.

Konturek, P.C.; Brzozowski, T.; Pajdo, R.; Nikiforuk, A.; Kwiecień, S.; Harsch, I.; Drozdowicz, D.; Hahn, E.G. \& Konturek, S.J. (2004). Ghrelin - a new gastroprotective factor in gastric mucosa. Journal Physiology and Pharmacology, Vol.55, No.2, pp.325-336, ISSN 0867-5910.

Konturek, P.C.; Brzozowski, T.; Burnat, G.; Szlachcic, A.; Koziel, J.; Kwiecien, S.; Konturek, S.J. \& Harsch, IA. (2010). Gastric ulcer healing and stress-lesion preventive properties of pioglitazone are attenuated in diabetic rats. Journal Physiology and Pharmacology Vol.61, No 4, pp.429-36, ISSN 0867-5910.

Konturek, P.C., Konturek, S.J., Burnat, G., Brzozowski, T., Brzozowska, I., Reiter, R.J. (2008). Dynamic physiological and molecular changes in gastric ulcer healing achieved by melatonin and its precursor L-tryptophan in rats. Journal of Pineal Research. Sep;45(2), pp.180-90, ISSN 1600-079X.

Konturek, S.J.; Stachura, J.; Radecki, T.; Drozdowicz, D. \& Brzozowski, T. (1987). Cytoprotective and ulcer healing properties of prostaglandin $\mathrm{E}_{2}$, colloidal bismuth and sucralfate in rats. Digestion, Vol.38, No.2, pp.103-113, ISSN 00122823. 
Konturek, S.J; Brzozowski, T.; Bielanski, W. \& Schally, A.V. (1995). Role of endogenous gastrin in gastroprotection. European Journal of Pharmacology, Vol.278, No.3, pp.203-212, ISSN 0014-2999.

Lagaud, G.J.; Young, A.; Ascena, A.; Morton, M.F.; Barrett, T.D. \& Shankley, N.P. (2007). Obestatin reduces food intake and suppresses body weight gain in rodents. Biochemical and Biophysical Research Communications, Vol.357, No.1, pp.264-269, ISSN 0006-291X.

Lesch, C.A.; Gilbertsen, R.B.; Song, Y.; Dyer, R.D.; Sehrier, D.; Kraus, E.R.. \& Sanchez, B.; Guglietta A. (1998). Effect of novel anti-inflammatory compounds on healing of acetic acid-induced gastric ulcer in rats. Journal of Pharmacology and Experimental Therapeutics, Vol.287, No.1, pp.301-306, ISSN 0022-3565.

Lugarini, F.; Hrupka, B.J.; Schwartz, G.J.; Plata-Salaman, C.R.; Langhans W. (2002). A role for cyclooxygenase-2 in lipopolysaccharide-induced anorexia nervosa in rats. American Journal Physiology, Vol.283, No.4, pp.R862-R868, ISSN 0002-9513.

Masuda Y, Tanaka T, Inomata N, Ohnuma N, Tanaka S, Itoh Z, Hosoda H, Kojima M, Kangawa K. (2000). Ghrelin stimulates gastric acid secretion and motility in rats. Biochemical and Biophysical Research Communications, Vol.267, No.3, pp.905-958, ISSN 0006-291X.

Moechars, D.; Depoortere, I.; Moreaux, B.; de Smet, B.; Goris, I. \& Hoskens, L.; Daneels, G.; Kass, S.; Ver Donck, L.; Peeters, T. \& Coulie B. (2006). Altered gastrointestinal and metabolic function in the GPR39-obestatin receptor-knockout mouse. Gastroenterology, Vol.131, No.4, pp.1131-1141, ISSN 0016-5085.

Mondal, M.S.; Nakazato, M.; Date, Y.; Murakami, N.; Yanagisawa, M.\& Matsukura, S. (1999). Widespread distribution of orexin in rat brain and its regulation upon fasting. Biochemical and Biophysical Research Communications, Vol.256, No.3, pp. 495-499, ISSN 0006-291X.

Nogueiras, R.; Pfluger, P.; Tovar, S.; Arnold, M.; Mitchell, S.; Morris, A.; Perez-Tilve, D.; Vázquez, M.J.; Wiedmer, P.; Castañeda, T.R.; DiMarchi, R.; Tschöp, M.; Schurmann, A.; Joost, H.G.; Williams, L.M.; Langhans, W. \& Diéguez, C. (2007). Effects of obestatin on energy balance and growth hormone secretion in rodents. Endocrinology, Vol.148, No.1, pp.21-26. ISSN 0013-7227.

Okabe, S.; Roth, J.L. \& Pfeiffer, C.J.(1971). A method for experimental penetrating gastric and duodenal ulcers in rats. American Journal of Digestive Diseases, Vol.16, No.3, pp.277-284, ISSN 0002-9211.

Peeters, T.L. (2005). Ghrelin: a new player in the control of gastrointestinal functions. Gut, Vol.54, No.11, pp.1638-1649, ISSN: 0017-5749.

Sakurai, T. (2003). Orexin. A link between energy homeostasis and adaptive behaviour. Current Opinion in Clinical Nutrition Metabolic Care, Vol.6, No.4, pp.353-360, ISSN 1363-1950.

Sakurai, T.; Amemiya.; A.; Ishii, M.; Matsuzaki, I.; Chemelli, RM, Tanaka, H.; Williams, S.C.; Richarson, J.A.; Kozlowski, G.P.; Wilson, S.; Arch, J.R.; Buckingham, R.E.; Haynes, A.C.; Carr, S.A.; Annan, R.S.; McNulty, D.E.; Liu, W.S.; Terrett, J.A.; Elshourbagy, N.A.; Bergsma, D.J. \& Yanagisawa, M. (1998). Orexins and orexin receptors: a family of hypothalamic neuropeptides and $G$ protein-coupled 
receptors that regulate feeding behaviour. Cell, Vol.92, No.4, pp.573-585, ISSN 0092-8674.

Scholz H. (2003). Prostaglandins. American Journal Physiology, Vol.285, No.3, pp.R512R514, ISSN 0002-9513.

Shujaa, N.; Zadori, Z.S.; Ronai, A.Z.; Barna, I.; Mergl; Z.; Mozes M.M. \& Gyires, K. (2009). Analysis of the effect of neuropeptides and cannabinoids in gastric mucosal defense initiated centrally in the rat. Journal Physiology and Pharmacology, Vol.60, Suppl.7, pp.93-100, ISSN 0867-5910.

Sibilia, V.; Rindi, G.; Pagani, F.; Rapetti, D.; Locatelli, V.; Torsello, A.; Campanini, N.; Deghenghi, R. \& Netti, C. (2003). Ghrelin protects against ethanol-induced gastric ulcers in rats: studies on the mechanisms of action. Endocrinology, Vol.144, No.4, pp.353-359, ISSN 0013-7227.

Sibilia, V.; Torsello, A.; Pagani, F.; Rapetti, D.; Lattuada, N.; Bocatelli, V.; Bulgarelli, I.; Guidobono, F. \& Netti C. (2004). Effects of hexarelin against acid-independent and acid-dependent ulcerogens in the rat. Peptides, Vol.25, No.12, pp.2163-2170, ISSN 0196-9781.

Sibillia, V.; Bresciani, E.; Lattuada, N.; Lattuada, N.; Rapetti, D.; Locatelli, V.; De Luca, V.; Donà, F.; Netti, C.; Torsello, A. \& Guidobono, F. (2006). Intracerebroventricular acute and chronic administration of obestatin minimally affect food intake but not weight gain in the rat. Journal of Endocrinological Investigation, Vol.29, No.11, pp.RC31-RC34, ISSN 0391-4097.

Smart, D.; Sabido-David, C.; Brough, S.J.; Jewitt, F.; Johns, A.; Porter, R.A. \& Jerman, J.C. (2001). SB-334867: the first selective orexin-1 receptor antagonist. British Journal of Pharmacology, Vol.132, No.6, pp.1179-1189, ISSN 0007-1188.

Takeuchi, K.; Tanaka, A.; Hayashi, Y. \& Kubo, Y. (2004). Functional mechanism underlying COX-2 expression following administration of indomethacin in rat stomachs: importance of gastric hypermotility. Digestive Diseases and Sciences, Vol.49, No.2, pp.180-187, ISSN 0163-2116.

Tanaka, A.; Araki, H.; Hase, S.; Komoike, Y. \& Takeuchi, K. (2002). Up-regulation of COX-2 by inhibition of COX-1 in the rat: a key to NSAID-induced gastric injury. Alimentary Pharmacology \& Therapeutics, Vol.16, Supl.2, pp.90-101, ISSN 0269-2813.

Tomasetto, C.; Karam S.M.; Ribieras S.; Masson R.; Lefebvre O.; Staub A.; Alexander G.; Chenard M.P.\& Rio M.C. (2000). Identification and characterization of a novel gastric peptide hormone; the motilin-related peptide. Gastroenterology, Vol.119, No.2, pp.395-405, ISSN 0016-5085.

Tremblay, F.; Perreault, M.; Klaman, L.D.; Tobin, J.F.; Smith, E. \& Gimeno, R.E. (2007). Normal food intake and body weight in mice lacking the G proteincoupled receptor GPR39. Endocrinology, Vol.148, No.2, pp.501-506. ISSN 00137227.

Tschop, M.; Smiley D.L. \& Heiman M. (2000). Ghrelin induces adiposity in rodents. Nature, Vol.407, No.6806, pp.908-913, ISSN 00228-0836.

Wren, A.M. \& Bloom S.R. (2007). Gut hormones and appetite control. Gastroenterology, Vol.132, No.6, pp.2116-2130, ISSN 0016-5085. 
Zhang, J.V.; Ren, P-G.; Avsian-Kretchner, O.; Luo, C-W.; Rauch, R.; Klein, C. \& Hsueh A.J. (2005). Obestatin, a peptide encoded by the ghrelin gene, opposes ghrelin's effects on food intake. Science, Vol. 301, No.5750, pp. 996-999, ISSN 0036-8075. 


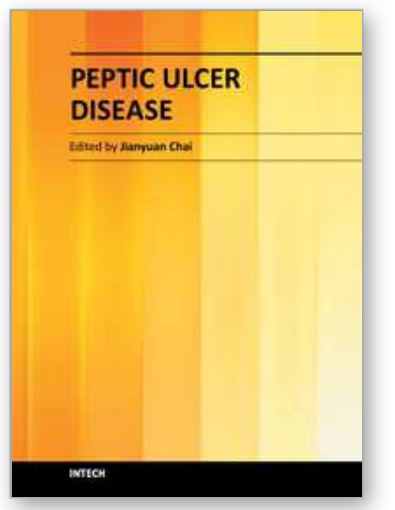

\author{
Peptic Ulcer Disease \\ Edited by Dr. Jianyuan Chai
}

ISBN 978-953-307-976-9

Hard cover, 482 pages

Publisher InTech

Published online 04, November, 2011

Published in print edition November, 2011

Peptic ulcer disease is one of the most common chronic infections in human population. Despite centuries of study, it still troubles a lot of people, especially in the third world countries, and it can lead to other more serious complications such as cancers or even to death sometimes. This book is a snapshot of the current view of peptic ulcer disease. It includes 5 sections and 25 chapters contributed by researchers from 15 countries spread out in Africa, Asia, Europe, North America and South America. It covers the causes of the disease, epidemiology, pathophysiology, molecular-cellular mechanisms, clinical care, and alternative medicine. Each chapter provides a unique view. The book is not only for professionals, but also suitable for regular readers at all levels.

\title{
How to reference
}

In order to correctly reference this scholarly work, feel free to copy and paste the following:

Thomas Brzozowski, Aleksandra Szlachcic, Robert Pajdo, Zbigniew Sliwowski, Danuta Drozdowicz, Jolanta Majka, Wladyslaw Bielanski, Peter. C. Konturek, Stanislaw J. Konturek and Wieslaw W. Pawlik (2011). Role of New Appetite Hormones Ghrelin, Orexin-A and Obestatin in the Mechanism of Healing of Chronic Gastric Ulcers, Peptic Ulcer Disease, Dr. Jianyuan Chai (Ed.), ISBN: 978-953-307-976-9, InTech, Available from: http://www.intechopen.com/books/peptic-ulcer-disease/role-of-new-appetite-hormones-ghrelin-orexin-a-andobestatin-in-the-mechanism-of-healing-of-chronic-

\section{INTECH}

open science | open minds

\section{InTech Europe}

University Campus STeP Ri

Slavka Krautzeka 83/A

51000 Rijeka, Croatia

Phone: +385 (51) 770447

Fax: +385 (51) 686166

www.intechopen.com

\section{InTech China}

Unit 405, Office Block, Hotel Equatorial Shanghai

No.65, Yan An Road (West), Shanghai, 200040, China 中国上海市延安西路65号上海国际贵都大饭店办公楼405单元

Phone: +86-21-62489820

Fax: $+86-21-62489821$ 
(C) 2011 The Author(s). Licensee IntechOpen. This is an open access article distributed under the terms of the Creative Commons Attribution 3.0 License, which permits unrestricted use, distribution, and reproduction in any medium, provided the original work is properly cited. 